\title{
norden
}

\section{Articles treated with antibacterial agents}

Outline of a strategy to reduce unjustified use

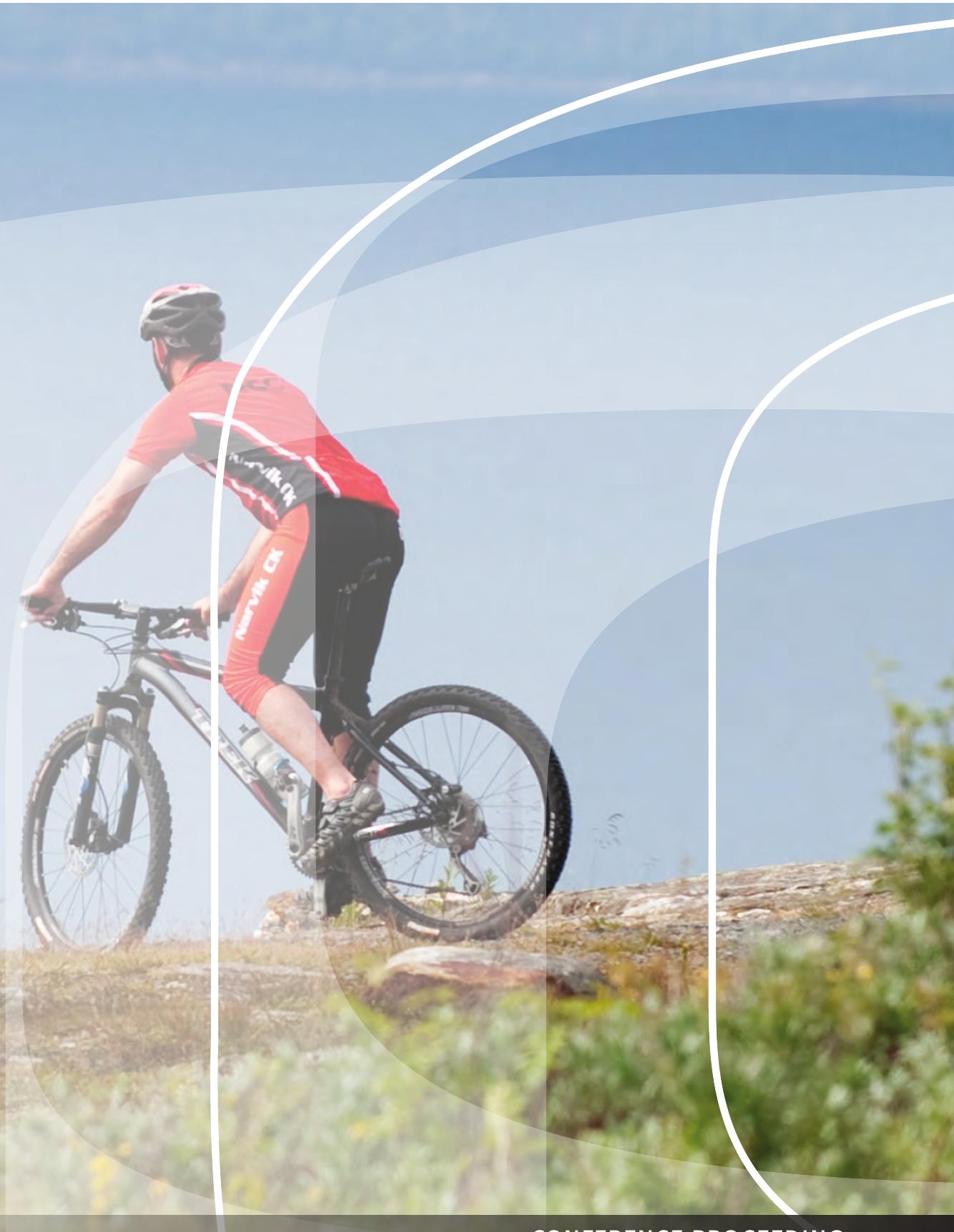



4 norden 



\section{Articles treated with antibacterial agents}

Outline of a strategy to reduce unjustified use

Lolo Heijkenskjöld

TemaNord 2014:513 
Articles treated with antibacterial agents

Outline of a strategy to reduce unjustified use

Lolo Heijkenskjöld

ISBN 978-92-893-2724-4

http://dx.doi.org/10.6027/TN2014-513

TemaNord 2014:513

ISSN 0908-6692

(C) Nordic Council of Ministers 2014

Layout: Hanne Lebech

Cover photo: ImageSelect

This publication has been published with financial support by the Nordic Council of Ministers. However, the contents of this publication do not necessarily reflect the views, policies or recommendations of the Nordic Council of Ministers.

www.norden.org/en/publications

Nordic co-operation

Nordic co-operation is one of the world's most extensive forms of regional collaboration, involving Denmark, Finland, Iceland, Norway, Sweden, and the Faroe Islands, Greenland, and Åland.

Nordic co-operation has firm traditions in politics, the economy, and culture. It plays an important role in European and international collaboration, and aims at creating a strong Nordic community in a strong Europe.

Nordic co-operation seeks to safeguard Nordic and regional interests and principles in the global community. Common Nordic values help the region solidify its position as one of the world's most innovative and competitive.

\section{Nordic Council of Ministers}

Ved Stranden 18

DK-1061 Copenhagen K

Phone (+45) 33960200

www.norden.org 


\section{Content}

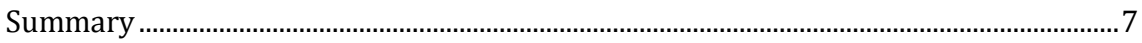

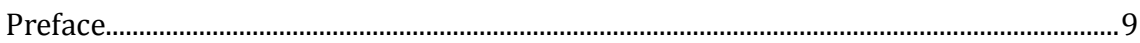

1. Introduction and scope..................................................................................... 11

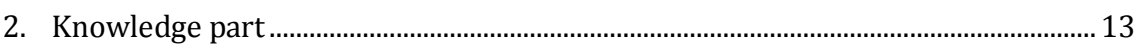

2.1 Biocides, metals and antibiotics as drivers for antibiotic resistance........... 13

2.2 An Internet survey of biocide treated articles ............................................... 15

2.3 New provisions regarding articles treated with biocides.............................. 17

2.4 Efficacy assessment of treated articles............................................................. 18

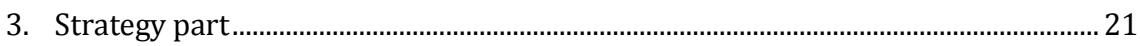

3.1 Introduction to a method for strategic planning............................................. 21

3.2 The Problem Tree.......................................................................................... 22

3.3 The Objective Tree .............................................................................................. 22

3.4 Specific objectives and activities.................................................................. 23

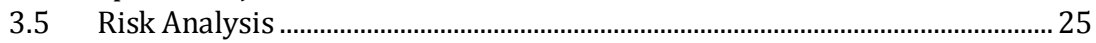

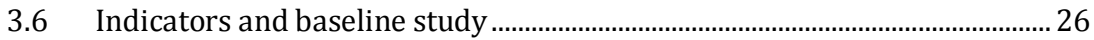

3.7 The first steps in a continued Nordic cooperation ........................................ 27

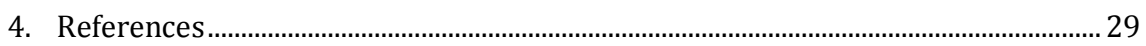

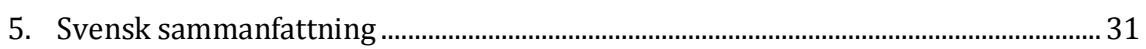

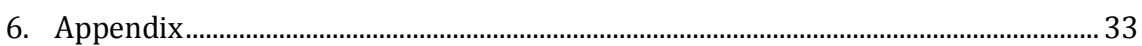

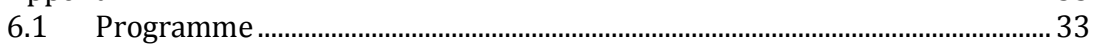

6.2 List of participants ...................................................................................... 34 



\section{Summary}

This workshop was held to initiate a Nordic collaboration to develop a strategy concerning the use of antibacterial substances in articles. Such a strategy could be the platform for actions to reduce this use and the risk of bacterial resistance related to it.

Workshop participants came from authorities in Finland, Denmark, Norway, Iceland and Sweden. They were given background information on the development of bacterial resistance to antibiotics and its relation to the use of biocides. The new EU provisions for the labelling of biocide treated articles, that will enable consumers to make informed choices, were also presented.

As further background, a survey showed that treated articles are marketed globally, and mostly without any information about biocides used. Effects like "anti-bacterial" or "anti-odour" were claimed for a vast amount of everyday articles, but information to support these claims was generally missing. Also, an overview of available methods for assessing the efficacy of biocide treatments indicated that there are no standard methods for cases where the treatment is intended to add new properties to the article, for example that development of odour during use is prevented.

Based on this background, the participants felt that the potential link to antibiotic resistance was worrying and that the treatment of articles represents a biocide use that is not always necessary and sometimes has no meaning at all. Methods to show the efficacy of this biocide use are not always available. New obligations enter into force but the party responsible for compliance does not seem prepared to implement them.

A method for strategic planning was then introduced and applied to start the elaboration of a Nordic strategy. It was agreed that a more sensible way of using biocides is needed and that the main objective should be Biocides are used properly. In the discussion, participants found that the detailed objectives Claims are specific, Manufacturers have enough knowledge and Consumers have enough knowledge were most important for achieving the main objective. Furthermore, activities were identified that would need to be carried out in order to reach each specific objective. 
In strategic planning it is vital to analyze risks relating to a proposed initiative. In this case, the most important risk identified was a potential lack of resources for further work. Therefore, workshop participants intended to consult within their organisations regarding the outlined actions.

Participants did, however, find it efficient to cooperate during the upcoming national work to inform article manufacturers and importers; and the same applied to information to the general public. Also, a coordinated base-line study should map the current situation, and here the results from existing studies would be useful.

The claimed effects of biocide treatment should be targeted in the strategy. Criteria will need to be developed for when treated articles represent an improper use of biocides and justification for cases where the treatment is seen as a proper use. A study on how claimed benefits are substantiated for other product categories might present useful illustrations for the development of guidance.

Provided that internal support and resources could be found, the participants agreed to summarize the first steps in a continued Nordic collaboration as:

- Look into EU legislation for other product categories in order to get an overview of how claimed qualities are verified in other contexts.

- Map the current situation regarding issues such as how widespread the biocide use in articles is, which biocides are used most frequently, exposure estimates for humans and the environment, in particular the aquatic environment. The potential for increased bacterial resistance also belongs to these issues. The purpose is to describe the scope of the problem and to establish a baseline for future work.

- Plan and initiate concrete and visible actions to raise knowledge of the problem among consumers and industry. Such actions may involve information campaigns, leaflets and web-site information. 


\section{Preface}

This is a report on the proceedings of a Nordic workshop that was held in Stockholm 26-27 August 2013. The theme for the workshop was "Knowledge and common strategy for articles treated with antibacterial substances."

The workshop was funded by the Nordic Council of Ministers and was an activity within the environment programme for the Swedish presidency of this council in 2013.

Workshop participants were invited both by a formal letter to the relevant national authorities in the Nordic countries and through the informal network of the Nordic Biocide Group, a project group under the Nordic Chemicals Group. Thirteen representatives from authorities in Finland, Denmark, Norway, Iceland and Sweden took part in the workshop.

The Swedish Chemicals Agency organized the workshop on behalf of the Swedish Ministry of the Environment and as part of its action plan for a toxic-free everyday environment. The work was led by Lolo Heijkenskjöld, Senior Scientific Officer, department for Development of legislation and other instruments at the Swedish Chemicals Agency.

The workshop discussions were moderated by Anders Ingelstam from Ingelstam $\mathrm{AB}$ and minutes from the discussions were taken by Pär Svahnberg, senior consultant at Trossa AB. 



\section{Introduction and scope}

Helena Casabona, Head of Unit for Co-ordination and authorisations, with recent responsibilities for Biocidal products and GMO at the Swedish Chemical Agency welcomes the participants and introduces the workshop subject.

The planning of this workshop has been triggered by new provisions in the Biocidal Product Regulation that will apply from 1 September 2013. These rules concern articles that are produced within as well as imported into EU. In brief, they shall ensure that treated articles contain only active substances that are allowed within EU and that article users are informed by a label when an article contains active substances for the purpose of a claimed biocidal effect.

The theme for this workshop is, however, limited to antibacterial treatment of articles, but lessons learned through strategic work in this area will surely be useful also in relation to articles that are treated with other kinds of biocides.

Other boundaries concern implementation issues that are still under discussion between competent authorities, as they cannot be resolved in this workshop. Enforcement projects for the new provisions are being planned in other bodies and so they should not be discussed here in any detail. In addition, we should bear in mind that many other authorities are dealing with the general problems relating to antibiotics and that the focus here is on possible links between bacterial resistance and the specific use of biocides for article treatment.

So, the workshop is built in two blocks, one for knowledge and one for strategy discussions. The knowledge block is intended to set the antibacterial treatment into its context and to shed some light on the dimensions of the related problems. It starts with a lecture on recent findings from research on bacterial resistance development and its relation to the use of biocides. The knowledge block also includes presentations of a survey of treated articles on the global market, the details in the new provisions for treated articles in the Biocidal Product Regulation and recent work on efficacy assessment of treated articles.

After that, a method for strategic planning will be introduced and applied during the second block of the workshop. Discussions will be 
guided and moderated to identify the problem, draw up the objective, analyze the base-line and other necessary elements of a strategy.

As a last piece of introduction, the view of Lena Ek, Swedish Minister of the Environment is presented by Jerker Forssell, Deputy Director at the ministry. A strategy that leads to a reduced use of antibacterial substances in articles will help preventing bacterial resistance and diminish adverse effects on human health and the environment. For this, cooperation with others will be necessary and traditionally, Nordic cooperation in the chemicals area has been very successful. It is therefore anticipated that also this workshop will be fruitful and give important results. 


\section{Knowledge part}

\subsection{Biocides, metals and antibiotics as drivers for antibiotic resistance}

Joakim Larsson, Professor in Environmental Pharmacology at the Sahlgrenska Academy, University of Gothenburg, introduces some aspects of bacterial resistance to antibiotics.

Bacteria may acquire resistance through mutations of pre-existing DNA or by uptake of entire genetic elements (genes) that are coding for resistance.

Environmental researchers on one hand, and clinical researchers or physicians on the other, tend to use somewhat different definitions of acquired antibiotic resistance:

- Bacteria showing a decreased sensitivity compared to the wild-type.

- Bacteria displaying a decreased sensitivity to an extent that an infection is not treatable.

There is a correlation between the increase in use of antibiotics and the prevalence of resistance. Antibiotics were introduced on a broad scale some 70 years ago, and at that time almost all pathogenic bacteria were sensitive. Currently, the resistance to antibiotics is increasing in different pathogens all over the world and development during the last 15 years is frightening.

Resistance, however, is neither a new nor an unnatural phenomenon. Antibacterial substances have always been produced by microorganisms and resistance genes can be found in 30,000 year old permafrost. It has recently become clear that resistance genes in human pathogens can be identical to those in environmental bacteria, suggesting an ongoing exchange of genes. This would mean that some $5 \times 10^{30}$ procaryotic cells in the environment most likely constitute a reservoir of resistance genes. The risk for transfer of resistance genes to human pathogens increases with selection pressure (ref: N. J. Ashbolt et al.).

Even very low concentrations of antibiotic substances may help creating a selection pressure for resistant bacteria. Antibiotics inhibit growth and reduce the reproduction of sensitive wild type bacteria, while 
bacteria with decreased sensitivity survive and can pass on their resistance genes to next generation. Because of this, resistance can be maintained and even increase over generations. The minimal selective concentrations (MSC) are lower, sometimes muc lower, than minimal growth inhibiting concentrations (MIC), which is targeted in therapy. Overall, it is clear that the external environment plays a role in the development of resistance, but it is yet to be demonstrated exactly where and under what circumstances this process is affected by human activities.

One environment where there is no doubt that the selection pressure is sufficient for antibiotic-resistant bacteria is around certain antibiotic manufacturing plants. Concentrations of pharmaceutical ingredients have been measured in different environmental matrices in Hyderabad, India. This is a global center for bulk drug production where more than a hundred company plants are situated within a concentrated area. The wastewater from these plants contains exceptionally high levels of many pharmaceutical residues. For example, the broad spectrum antibiotic ciprofloxacin is found in concentrations up to $30 \mathrm{mg}$ per liter, well exceeding the MIC values for sensitive wild-type bacteria and also well over the plasma levels in humans undergoing therapy. As a consequence of exposure to this wastewater cocktail of pharmaceuticals, all bacteria studied here are multi-resistant. Different management options for reducing the spread of antibiotics and genetic determinants for antibiotic resistance via environmental pathways have been proposed, and several practical initiatives have also been taken (ref: A. Pruden et al.).

Resistance caused by antibacterial biocides or metals can potentially accelerate the development of resistance to antibiotics. The explanation behind this is that the biocide or metal resistance genes may reside in close genetic vicinity of the antibiotic resistance genes within the same bacterial cell, thus the selection pressure created by a biocide will not only select for biocide resistant bacteria but also for those that are antibiotic resistant. This phenomenon is referred to as co-resistance.

Another possibility, referred to as cross-resistance, is that the same mechanism is utilized for resistance, e.g. when a bacterial membrane pump exports the antibiotic compound as well as the biocide. The role of antibacterial biocides and metals in antibiotic resistance development is not sufficiently studied, but has been identified and, based on available data, assessed by the Scientific Committee on Emerging and Newly Identified Health Risks (ref: SCENIHR).

There is a difference in use patterns for biocides and antibiotics in that biocides mostly have to be used in high concentrations in order to 
be effective while antibiotics have to be given in low doses to protect patients from severe side effects. At the high doses used, most biocides act on several targets within the bacterial cells. As a consequence of such "normal" biocide use, the resistance development at target site would presumably be rather rare. However, when biocides are used for treated articles, the release of active substances will be quite low and create a constant low exposure for microorganisms in the wastewater systems. Although minimal selective concentrations have not been established for biocides, it is quite possible that the diffuse release from biocide treated articles can trigger resistance development. The scientific background does not allow a more firm statement.

In some cases the use of biocides may even help reducing the use of antibiotics, for example when risks of bacterial infections induced by medical devices are diminished through biocidal treatment of the device.

Joakim Larsson concludes by describing INTERACT, a new research programme funded by the Swedish Research Council FORMAS. Among other things, this programme will look into the presence of resistance to biocides and metals in different environments, and the concentrations of these compounds that promote bacterial resistance to antibiotics. He also refers to a database on antibacterial biocides and metal resistance genes that has recently been developed under the research programme, available at http://bacmet.biomedicine.gu.se/

When asked how authorities best should start working with treated articles, he recommends the identification of uses where antibacterial treatment cannot in any way be considered necessary.

\subsection{An Internet survey of biocide treated articles}

Lolo Heijkenskjöld, Senior Scientific Officer at the Swedish Chemicals Agency, presents the results of an Internet survey of treated consumer articles on the global market (ref: PM 2/12).

This survey was conducted in order to answer questions concerning active substances used, the frequency of consumer article treatment and claimed treatment effects. As there are no standard methods to find such answers, a search procedure had to be created during the work. 
Although relevant substances in product types 2, 7 and 9 (defined in Annex V of the Biocidal Product Regulation) ${ }^{1}$ were used as starting point for the search, an important conclusion is that information on active substances used is very limited. Trade names of the biocidal product used could be shown, but in most cases no information about the active substance was disclosed.

The results of the survey show that a vast amount of treated articles for everyday use could be found, but only when searching for article types and brand names in combination with terms like "antibacterial" or "anti-odour" for the claimed effect. Articles intended for use in many daily activities could be found, for example:

- home textiles, clothing and shoes

- interior building materials

- kitchen, bathroom and cleaning equipment

- office supplies, sports wear

- childcare articles.

Another conclusion is that Internet marketing provides no information to support the claimed effects. In general, the claims made seem to play on customers' fear of unseen and unknown microorganisms and to give an impression of safety. The table below gives some very clear examples from the survey.

\footnotetext{
1 Product type 2: Disinfectants and algaecides not intended for direct application to humans or animals. Products used for the disinfection of surfaces, materials, equipment and furniture which are not used for direct contact with food or feeding stuffs. Usage areas include, inter alia, swimming pools, aquariums, bathing and other waters; air conditioning systems; and walls and floors in private, public, and industrial areas and in other areas for professional activities. Products used for disinfection of air, water not used for human or animal consumption, chemical toilets, waste water, hospital waste and soil. Products used as algaecides for treatment of swimming pools, aquariums and other waters and for remedial treatment of construction materials. Products used to be incorporated in textiles, tissues, masks, paints and other articles or materials with the purpose of producing treated articles with disinfecting properties. Product type 7: Film preservatives. Products used for the preservation of films or coatings by the control of microbial deterioration or algal growth in order to protect the initial properties of the surface of materials or objects such as paints, plastics, sealants, wall adhesives, binders, papers, art works.

Product-type 9: Fibre, leather, rubber and polymerised materials preservatives. Products used for the preservation of fibrous or polymerised materials, such as leather, rubber or paper or textile products by the control of microbiological deterioration. This product-type includes biocidal products which antagonise the settlement of micro-organisms on the surface of materials and therefore hamper or prevent the development of odour and/or offer other kinds of benefits.
} 


\begin{tabular}{|c|c|}
\hline Article trade name & Claimed effect \\
\hline $\begin{array}{l}\text { Rachel Ray Knife Gusto } \\
\text { Grip }\end{array}$ & $\begin{array}{l}\text { New antimicrobial inhibitors are incorporated directly and permanently into the } \\
\text { handles }\end{array}$ \\
\hline $\begin{array}{l}\text { Grundig hand vacuum } \\
\text { cleaner }\end{array}$ & Antibacterial Microbes Hygiene protection in filters and container \\
\hline $\begin{array}{l}\text { Swipe washing ball } \\
\text { (antibacterial) }\end{array}$ & $\begin{array}{l}\text { The ball has a core of fibers with silver nitrate ions. At each washing it emits } \\
\text { billions of ions, which effectively ensures that the bacteria disappear }\end{array}$ \\
\hline Garbage bags & $\begin{array}{l}\text { The bags have a special antimicrobial additive that prevents from developing } \\
\text { bacteria and other pathogens }\end{array}$ \\
\hline Leather insoles & $\begin{array}{l}\text { These leather insoles help keep your feet dry, odourless and with their } \\
\text { antibacterial properties, guarantee optimal foot hygiene }\end{array}$ \\
\hline $\begin{array}{l}\text { Benny the Bear } \\
\text { antimicrobial stuffed } \\
\text { teddy bear }\end{array}$ & $\begin{array}{l}\text { World's first anti-microbial toy protects the product and your children against } \\
\text { bacteria, mites or mold and kills odor-causing bacteria }\end{array}$ \\
\hline
\end{tabular}

\subsection{New provisions regarding articles treated with biocides}

Ulrike Frank, Senior Scientific Officer at the Swedish Chemicals Agency, presents the new provisions for biocide treated articles in the Biocidal Product Regulation (ref: Regulation (EU) No 528/2012).

The term "treated article" is defined to mean any substance, mixture or article which has been treated with, or intentionally incorporates, one or more biocides (Article 3 (l)). However, treated articles with primary biocidal functions are considered as biocidal products (Article 3 (a) last paragraph).

The provisions do not apply to articles which have only been treated during fumigation or disinfection for storage / transport and which are not expected to contain residues from the treatment (Article 58. 1).

Article 58 states that treated articles may only be placed on the EU market if the biocidal products used for the treatment contain active substances that have been approved in the EU for the relevant product type and use. This is relating to the conditions for approval of active substances, where product type and manner and area of use, including the use in treated articles, shall be specified (Article 4.3). To illustrate that many different exposure categories will be possible, Ulrike Frank mentions that anti-odour treatment of textiles in clothes can give rise to long term dermal contact while anti-mold treated shower-curtains lead to negligible dermal contact. 
Article 58 also states that the person placing a treated article with a claimed biocidal property on the market is required to label the article. The label shall give the following information:

- that the article contains a biocidal products,

- where substantiated, the biocidal property of the article,

- the name of all active substances contained,

- the name of the nanomaterials contained,

- relevant instructions for use and precautionary measures.

The requirements in Article 58 apply from 1 September 2013. The transitional measures in Article 94 are however under revision and still subject to changes. The revision is expected to allow articles treated with an active substance, which is part of the review programme for the relevant product type, to be placed on the market until the decision is taken for that active substance. In cases where these conditions do not apply, i.e. the combination of active substance and product type is not part of the review programme, an additional dossier for use of the active substance in treated articles have to be submitted by 1 September 2016. Otherwise the treated article may not be placed on the market after 1 March 2017.

Furthermore, there are ongoing discussions between the Commission and Member States on how to interpret the term "treated article with a primary biocidal function." The Commission has suggested that treated articles with health claims generally give rise to the presumptions that they have primary biocidal functions. The outcome of these discussions will be of great importance as biocidal products need pre-market authorizations, while this does not apply to treated articles.

\subsection{Efficacy assessment of treated articles}

Peter Askew from Industrial Microbiological Services Ltd presents his work for a Nordic project on guidance for how the efficacy of biocide treatment of articles can be tested and confirmed (Nordic Working Papers 2014:904).

The first part of the presentation concerns cases where the biocide treatment is intended to protect the properties of a material and/or extend the durability of an article. Some examples of such cases are: 
- prevent the deterioration of plasticised PVC

- prevent short-circuits due to the deterioration of electrical insulation sleeves

- prevent odour.

In cases like these, the consequences of non-protection can easily be observed and lead to complaints that get forwarded up the supply chain (except maybe in the case of odour). Biocide producers are normally aware of this type of end use for their products.

A variety of test methods is available to confirm the protective effects by showing that the untreated material deteriorates in a way that the treated material does not. The claim about preventing odour is again an exception, as there are currently no test methods available for this effect.

The second part of the presentation concerns treatments intended to add new properties to an article; i.e. properties that do not relate to its primary function. Some examples where the treatment is supposed to add new properties are:

- computer keyboards treated to prevent bacterial growth

- hospital bedside cabinets treated to kill microorganisms on contact

- door handles treated to prevent cross-infection.

In general, these cases are intended to improve hygiene. Adding antimicrobial properties is seen as something desirable. But hypothetical hazards are often being addressed and the benefits can be unclear to the consumer.

There are no standard test methods to support this type of claims. The claimed effects must be demonstrated under realistic conditions of use of the article and so simulation tests have to be used. It should also be shown that microorganisms associated with the untreated article represent a significant problem. For example, are bacteria growing on the computer keyboard? Do microorganisms pose a hazard by simply being on a surface?

The study report will be presented and discussed in a meeting for the biocide competent authorities in the EU Member States. 



\section{Strategy part}

The knowledge part of this workshop has made the current situation quite clear. In the discussion, workshop participants see the possible links to antibiotic resistance as extremely worrying, and agree that the problem is global and requires international cooperation.

It is problematic that biocide treatment of articles represents a use that is not always absolutely necessary and sometimes has no meaning at all. It is also problematic that methods to show the efficacy of this biocide use are not always available. New obligations enter into force but the party responsible for the compliance does not seem to be well prepared to implement them.

\subsection{Introduction to a method for strategic planning}

The moderator Anders Ingelstam from Ingelstam $A B$ presents the groundwork of strategic planning and also refers to his book "Practical Practitioners Guide to Strategic Planning." He warns of over ambitious and inflated expressions and speaks warmly of simple objectives and concrete activities.

The aim of this workshop is to start a Nordic collaboration for a strategy concerning treated articles. A vision, that illustrates how the situation would ideally be, is the first thing needed when developing a strategy. In our case, the problems with the current situation have been described already and a proposed ideal situation is "a proper biocide use, in which the use of biocides is limited to the minimum necessary."

This expression is a reference to Article 17. 5 in the Biocidal Product Regulation, which should be well known for those involved with biocide work. Although the expression is meant to imply a future, more sensible way of using biocides, it can however be misinterpreted as a neat and tidy use situation; therefore it sometimes gets referred to as "wisely" during the discussions. 
Anders Ingelstam emphasizes the importance of correct problem formulation in strategic planning. Problems should always be expressed as a negative state and they should never include a missing solution. If you include a missing solution in the problem then your search will be limited to that solution. The door will be closed for all other ideas and solutions.

So the problem identified as a starting point for this strategy is that biocides are not used properly.

\subsection{The Problem Tree}

In the next step, the discussion is focused on what causes the problem, and on how this strategy can influence these causing factors. They can be organized into a Problem Tree, to show that six underlying problems together are causing the fundamental problem.

\section{The Problem Tree}

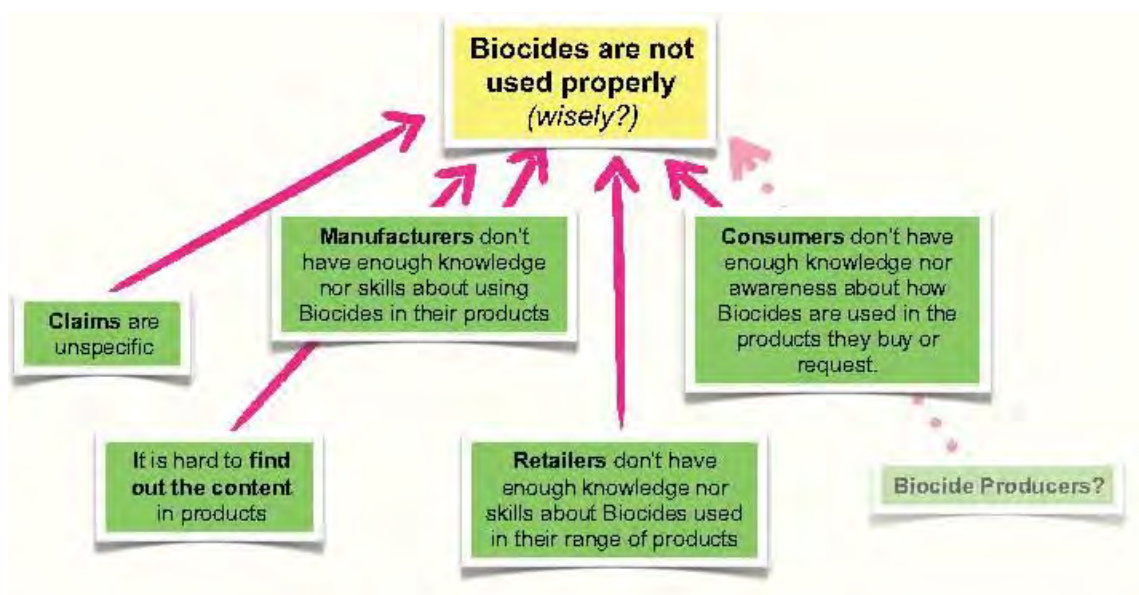

\subsection{The Objective Tree}

A very simple reformulation of the identified problem will give useful objectives. By removing the negation, the original problem will become the objective: Biocides are used properly. This objective mirrors the problem but is expressed as a positive state. The same thing is done for all underlying problems, to create a set of objectives that illustrates what we want to achieve. 
The logic in this Objective Tree is that the fulfillment of objectives on one level will contribute to achieving objectives on the level above.

\section{The Objective Tree}

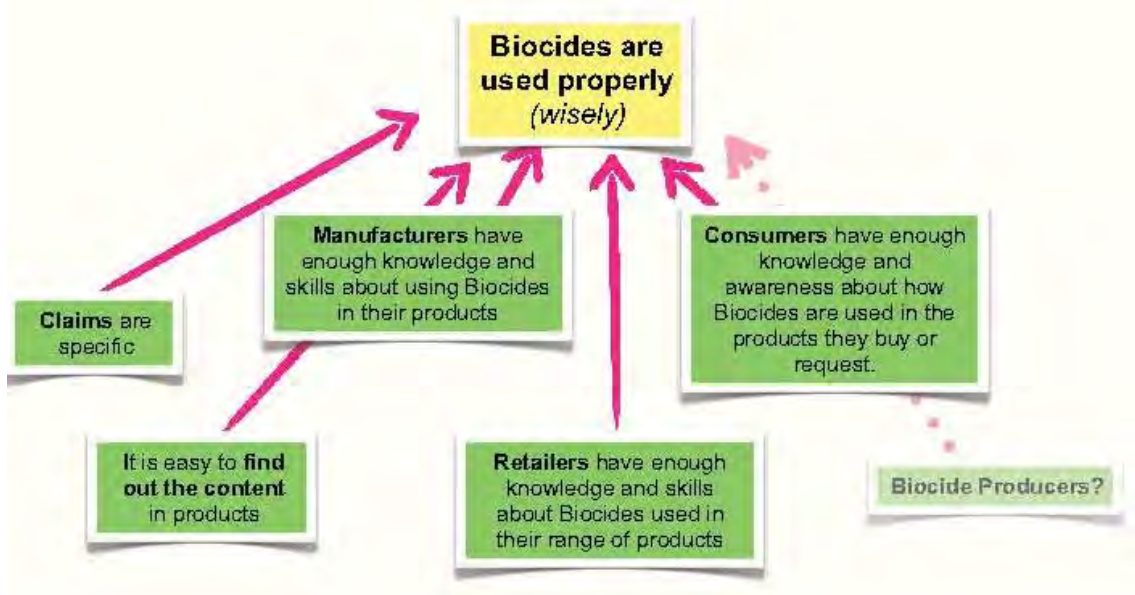

In order to prioritize in The Objective Tree, a simple voting procedure is performed. Each participant puts three red stickers on the objective / objectives that seem most important to them. According to the voting results, Claims are specific, Manufacturers have enough knowledge and Consumers have enough knowledge clearly are the most important objectives for a common Nordic strategy.

\subsection{Specific objectives and activities}

In the next step, workshop sub-groups identify three specific objectives for the prioritized objectives. The sub-groups also match their specific objectives with three activities each, i.e. activities that need to be carried out in order to reach that objective. Here, it is important that activities are phrased to contain a verb. The following elements can then be added to the Objective Tree. 


\subsubsection{Claims are specific}

First specific objective: Efficacy of treatment is documented

- Consultant to collect examples of claimed effects.

- Select from the collected examples cases that illustrate claim problems.

- Propose ways to substantiate efficacy in selected claim examples.

Second specific objective: Clear guidance is available

- Develop draft guidance together with industry and other NGOs.

- Identify similar cases, gaps and overlaps in other areas of legislation (General Product Safety, Medical Devices, Food Contact Materials etc).

Third specific objective: Legislation is clear

- Draft a proposal for clarification of the requirements in article 58.

- Coordinate and present the proposal widely.

- Submit the proposal when the Commission is examining the need for additional measures in view of a sustainable use of biocidal products (before July 2015, according to Article 18 of the regulation).

\subsubsection{Manufacturers have enough knowledge}

First specific objective: Economic incentives

- Tax on certain product groups for use of biocide.

- Less tax on environmental labels on certain products.

- Waste management to be more expensive if biocides are discharged.

\section{Second specific objective: Legal requirements}

- The need for the treatment has to be justified on the label.

- Cooperation with other authorities.

\section{Third specific objective: Demands from consumers/NGOs}

- Dialogue, information campaign, education, risk benefit analysis.

- Authorities gather information about biocide use in products and if it has any effects. 


\subsubsection{Consumers have enough knowledge}

First specific objective: Consumer information is easily accessible

- The new labeling requirements for treated articles will allow consumers to make informed choices. Prepare press info/website info about these requirements and about the consumers' "right to know in 45 days."

- Produce leaflets to be distributed e.g. at doctors' offices.

Second specific objective: Information is simple and understandable

- Draft guidance for article manufacturer how to place labelling info.

- Courses for personnel in agencies, health care and general education

- Produce information in simple language.

Third specific objective: Consumers have enough knowledge to deal with the information

- Carry out a coordinated information campaign: leaflets, web information.

- Communicate the message that bacteria and humankind have always co-existed.

- Use different communication channels such as government websites, brochures and targeted mailing to reach as many as possible.

\subsection{Risk Analysis}

For the strategy to be successful, it is best to perform a risk analysis, i.e. to try to foresee all related risks and minimize them as far as possible.

A risk matrix will quickly give an overview of the risks associated with a project. The foreseen risks are listed as in the matrix and their possible impacts are judged by estimating their probability and damage (ratings 1-5). Such a swift exercise gave the example below. When managing the risks, focus should be on the risks that have high impacts.

Overview of risks and potential impacts (example)

\begin{tabular}{lccr}
\hline Risk & Probability (P) & Damage (D) & Impact (P x D) \\
\hline Lack of resources & 5 & 4 & 20 \\
Lack of support for proposal & 3 & 4 & 12 \\
Industry reactions & 4 & 2 & 8
\end{tabular}




\subsubsection{Affected parties}

A stakeholder analysis should be part of the risk analysis, as this will give a more detailed picture of the risks and contribute to the risk management. Who will be affected by the strategy? How will they react if the objectives are achieved? A selection of identified stakeholders is:

\begin{tabular}{ll}
\hline Positive & Negative \\
\hline Consumers & Biocide suppliers \\
Healthcare & Article manufacturers/importers \\
Waste water treatment & \\
\hline
\end{tabular}

Stakeholders that are positively affected should be allies while those who are adversely affected indicate risks that need to be managed.

\subsubsection{Risk management}

The four main lines in risk management are:

- Avoid - when this is possible, it is of course outstanding

- Control - by far the most common action

- Transfer - rarely applicable for us, it usually concerns transfer to; insurance companies

- Accept - often practiced for risks with low impacts.

To minimize the first risk in the example matrix above, lack of resources, it is crucial to have early endorsement for the initiative, to ensure that it is approved and funded.

For the second risk, lack of support for the proposal, it is important to reduce the probability by sufficiently broad consultations, and perhaps also justify the proposal by showing lessons learned and good examples from Nordic investigations.

\subsection{Indicators and baseline study}

When you have identified a number of specific objectives and activities to fulfill them, some indicators will be needed. The indicators' function is to monitor the progress of a project and indicating if it advances towards the objective. They can also help quantifying how far you need to reach. The selected indicators should be measurable and verifiable. 
Before establishing the expected level of change, it is essential to conduct a baseline study. In such a study you explore each indicator and its value at the beginning of the project. Only then can realistic targets be set for a project and the outcome measured and assessed. The baseline study is therefore an essential part of every serious plan for changes. Still, this step is often forgotten.

\subsection{The first steps in a continued Nordic cooperation}

In this workshop, time has not allowed any deeper analysis or more thorough discussion to apply all steps in strategic planning to the subject of treated articles. Brief exercises have however been carried out for all of them, except for selecting indicators and designing a baseline study.

The final workshop discussion concerns objectives and shared responsibilities for a continued Nordic cooperation. Participants agree on the importance of the treated article issue but need to discuss the workshop findings nationally to ensure internal support. As shown earlier, there is caution about the availability of resources.

Participants find it efficient to coordinate during the up-coming national work to inform article manufacturers and importers. The same applies for information to the general public. Also, a coordinated baseline study will be needed to map the current situation, and here the results from already existing studies will be useful.

The claimed effects of biocide treatment should be targeted in the strategy. Criteria need to be developed for when treated articles represent an improper use of biocides and justification for cases where the treatment ca be seen as a proper use. A study on how claimed benefits are substantiated for other product categories may illustrate paralell situations that will be useful for guidance development. In summary, the first steps for a continued Nordic collaboration should be:

- Reflect and consult on the findings and actions outlined in this report.

- Make an overview of provisions in other ares of EU legislation regarding claimed qualities or benefits for products/articles and how those claims are to be verified.

- Map the current situation regarding issues such as how widespread the biocide use in articles is, which biocides are most frequently used, exposure estimates for humans and the environment, in particular the aquatic environment. The potential for increased bacterial 
resistance also belongs to these issues. The purpose is to describe the scope of the problem and to establish a baseline for future work.

- Plan and initiate concrete and visible actions to raise knowledge of the problem among consumers and industry. Such actions may involve information campaigns, leaflets and web-site information. 


\section{References}

Sector program for the environment during the Swedish presidency 2013 of the Nordic Council of Ministers. Available at: http://dx.doi.org/10.6027/ANP2012-758

Ashbolt, N. J., Amézquita, A., Backhaus, T., Borriello, P., Brandt, K. K., Collignon, P., Coors, A., Finley, R., Gaze, W. H., Heberer, T., Lawrence, J. R., Larsson D. G. J., McEwen, S. A., Ryan, J. J., Schönfeld, J., Silley, P., Snape, J. R., C. Van den Eede and Topp, E. (2013): “Human Health Risk Assessment for Environmental Development and Transfer of Antibiotic Resistance." Environ Health Perspect No. 121, pp 9931001. Available at: http://dx.doi.org/10.1289/ehp.1206316

Pruden, A., Larsson, D.G. J., Amézquita, A., Collignon, P., Brandt, K. K., Graham, D. W., Lazorchak, J. M., Suzuki, S., Silley, P., Snape, J. R., Topp, E., Zhang, T. and Zhu, Y.-G. (2013): "Management Options for Reducing the Release of Antibiotics and Antibiotic Resistance Genes to the Environment." Environ Health Perspect No. 121, pp. 878-885. Available at: http://dx.doi.org/10.1289/ehp.1206446

SCENIHR, Scientific Committee on Emerging and Newly Identified Health Risks (2009): "Assessment of the Antibiotic Resistance Effects of Biocides." Opinion adopted at the 28th plenary on 19 January 2009. Available at: http://ec.europa.eu/ health/ph_risk/committees/04_scenihr/docs/scenihr_o_021.pdf

Database on antibacterial biocides and metal resistance genes. Available at: http://bacmet.biomedicine.gu.se/

Biocide treated articles - an Internet survey Available at: http://www.kemi.se/ Documents/Publikationer/Trycksaker/PM/PM2_12_Biocide_treated_articles.pdf

Regulation (EU) No 528/2012 of 22 May 2012 concerning the making available on the market and use of biocidal products, available at: http://eur-lex.europa.eu/ LexUriServ/LexUriServ.do?uri=0J:L:2012:167:0001:0123:EN:PDF

Anders Ingelstam (2010): "Practical Practitioners Guide to Strategic Planning." Nordic Working Papers 2014:904 Efficacy Assessment of Treated Articles. Se på side 18, kapitel 2.4, förste paragraf: Peter Askew. 



\section{Svensk sammanfattning}

Denna workshop avhölls för att inleda ett nordiskt samarbete för att utveckla en strategi gällande antibakteriella ämnen i varor. En sådan strategi kan utgöra plattform för åtgärder för att minska användningen och risken för bakterieresistens som orsakas av varor behandlade med antibakteriella ämnen.

Deltagarna i workshopen kom från myndigheter i Finland, Danmark, Norge, Island och Sverige. De fick inledningsvis bakgrundsinformation om utvecklingen av bakteriell resistens mot antibiotika och om hur den frhåller sig till användningen av biocider. De nya EU-bestämmelserna om märkning av biocidbehandlade varor, som ska stödja konsumenters medvetna val, presenterades också.

Som ytterligare bakgrund visade en undersökning att sådana varor marknadsförs globalt och för det mesta utan någon information om de biocider som använts. Påståenden om effekter som "anti-bacterial" eller "anti-odour" anges för ett stort antal behandlade konsumentprodukter, men stöd för dessa påståenden saknades i allmänhet. Dessutom visade en översikt av tillgängliga metoder för bedömning av effekten av biocidbehandling att det inte finns några standardmetoder då behandlingen ska tillföra varan nya egenskaper, som till exempel att dålig lukt under användningen ska förhindras.

Utgående från denna bakgrund, ansåg deltagarna att den eventuella kopplingen till antibiotikaresistens var oroväckande och att behandling av varor utgör en biocidanvändning som inte alltid är nödvändig och ibland inte har någon mening alls. Metoder för att visa effekten av denna biocidanvändning är inte alltid tillgängliga. Nya skyldigheter träder i kraft, men den part som ansvarar för efterlevnaden verkar inte vara beredd att genomföra dem.

En metod för strategisk planering introducerades och tillämpades sedan för utvecklingen av en strategi. Man enades om att biocider bör användas på ett mer förnuftigt sätt och att huvudsakligt mål för arbetet bör vara Biocides are used properly. I diskussionen, fann deltagarna att de mer specifika målen Claims are specific, Manufacturers have enough knowledge och Consumers have enough knowledge var viktigast för att uppnå det huvudsakliga målet. Vidare identifierades aktiviteter som behöver genomföras för att nå varje specifikt mål. 
I strategisk planering är det mycket viktigt att analysera riskerna för ett förslaget initiativ. I detta fall befanns den största risken vara bristen på resurser för fortsatt arbete. Därför avsåg deltagarna att samråda inom sina organisationer angående de föreslagna aktiviteterna.

Deltagarna fann dock att det vore effektivt att samarbeta i kommande nationellt arbete med information till varutillverkare och importörer; detsamma gällde information till allmänheten. Dessutom borde en baseline-studie göras för att kartlägga nuvarande situation, utgående från resultaten i befintliga studier.

Strategin bör inriktas mot biocidbehandlingens påstådda effektivitet. Kriterier för när en behandling kan anses utgöra en felaktig användning behöver utvecklas, liksom för när den kan vara motiverad. En studie av hur man för andra slags produkter underbygger påståenden om en produkts egenskaper skulle kunna ge användbara illustrationer till en vägledning.

Under förutsättning att internt stöd och resurstillgång kan ordnas, enades deltagarna om att sammanfatta de första stegen i ett fortsatt nordiskt samarbete som:

- Undersöka EU-lagstiftningen för andra produktkategorier för att få en överblick över hur produktens påstådda egenskaper verifieras i andra sammanhang.

- Kartlägga nuvarande situation vad gäller utbredningen av biocidbehandlade varor, vilka biocider som används oftast, uppskattad exponering för människa och miljö, särskilt vattenmiljön. Potentialen för ökad bakteriell resistens hör också till dessa frågor. Syftet är att beskriva omfattningen av problemet och fastställa utgångspunkten för det fortsatta arbetet.

- Planera och initiera konkreta och synliga åtgärder för ökad kunskap om problemet hos konsumenter och företag. Det kan gälla informationskampanjer, broschyrer och webb-sideinformation. 


\section{Appendix}

\subsection{Programme}

\section{Day 1}

Introductory note

Jerker Forssell

Workshop aim and delimitations

Helena Casabona

Biocides, metals and antibiotics as drivers for antibiotic

Joakim Larsson

resistance

An Internet survey of biocide treated articles

Lolo Heijkenskjöld

New provisions regarding articles treated with biocides

Ulrike Frank

How far can labelling requirements solve the problem?

Moderator

Discussion

Anders Ingelstam

Introduction to strategic planning - how to identify the

Anders Ingelstam problems and write clear objectives

Identification of objectives on different time horizons for a Nordic strategy. Discussion

Moderator

Anders Ingelstam

\section{Day 2}

Efficacy assessment of treated articles

Peter Askew

How far can requirements for description of claims and proof of effects solve the problem? Discussion

Moderator

Identification of activities and stakeholders. Shared responsibility for identified activities. Objectives and responsibilities in a continued Nordic cooperation. Discussion Anders Ingelstam

Moderator Anders Ingelstam

Summing up and closure of workshop

Helena Casabona 


\subsection{List of participants}

\begin{tabular}{|c|c|}
\hline Elín Ásgeirsdóttir & Advisor, Department for Sustainability, Environment Agency of Iceland \\
\hline Peter Askew & Industrial Microbiological Services Ltd (IMSL) \\
\hline Urban Boije af Gennäs & $\begin{array}{l}\text { Senior Scientific Officer, Strategies and assigned projects unit, Swedish } \\
\text { Chemicals Agency }\end{array}$ \\
\hline Helena Casabona & $\begin{array}{l}\text { Head of Unit for Co-ordination and Authorisations unit, Swedish Chemicals } \\
\text { Agency }\end{array}$ \\
\hline Birte Fonnesbech Vogel & Pesticides and Gene Technology, Danish Environmental Protection Agency \\
\hline Jerker Forssell & Deputy Director, Chemicals division, Swedish Ministry of the Environment \\
\hline Ulrike Frank & $\begin{array}{l}\text { Senior Scientific Officer, Evaluation of substances unit, Swedish Chemicals } \\
\text { Agency }\end{array}$ \\
\hline Kersti Gustafsson & Principal Scientific Adviser, EU co-ordination unit, Swedish Chemicals Agency \\
\hline Paula Haapasola & $\begin{array}{l}\text { Head of biocides group, Chemical Products Surveillance, Finnish Safety and } \\
\text { Chemicals Agency }\end{array}$ \\
\hline Terje Haraldsen & Senior adviser, Norwegian Environment Agency \\
\hline Lolo Heijkenskjöld & $\begin{array}{l}\text { Senior Scientific Officer, Strategies and assigned projects unit, Swedish } \\
\text { Chemicals Agency }\end{array}$ \\
\hline Anders Ingelstam & Ingelstam AB \\
\hline Monika Lahti & Sjefingeniør, Produktseksjonen, Norwegian Environment Agency \\
\hline Joakim Larsson & $\begin{array}{l}\text { Professor in Environmental Pharmacology,Sahlgrenska Academy, University } \\
\text { of Gothenburg }\end{array}$ \\
\hline Esa Nikunen & $\begin{array}{l}\text { Director, Chemical Products Surveillance, Finnish Safety and Chemicals } \\
\text { Agency }\end{array}$ \\
\hline Carina Näf & Head of Unit for Environmental assessment unit, Swedish Chemicals Agen \\
\hline Jaana Pasanen & Finnish Safety and Chemicals Agency \\
\hline Pär Svahnberg & sultant, Trossa $\mathrm{AB}$ \\
\hline
\end{tabular}


Nordic Council of Ministers

Ved Stranden 18

DK-1061 Copenhagen K

www.norden.org

\section{Articles treated with antibacterial agents}

Do we need antibacterial garbage bags? A wide range of antibacterial consumer articles can be found on the Internet. Mostly there is no information on the antibacterial agents used or on their efficacy.

Does this relate to bacterial resistance to antibiotics? The release of antibacterial agents from these articles creates a constant low exposure for microorganisms.This may help accelerating the development of bacterial resistance. Important research is on-going.

Can we know if an article contains antibacterial agents? New rules in EU legislation apply for treated articles. When implemented, information will be given if an article is treated for antibacterial effects and the claimed effects will be substantiated.

An outline for a strategy to prevent unjustified antibacterial articles was elaborated at a Nordic workshop, initiated by the Swedish presidency of the Nordic Council of Ministers.

TemaNord 2014:513

ISBN 978-92-893-2724-4

ISBN 978-92-893-2725-1 (EPUB)

ISSN 0908-6692 